\title{
Metabolic Acidosis in Acute Myocardial Infarction
}

\author{
M. A. NEAVERSON,* M.B., M.R.C.P.
}

Brit. med. F., 1966, 2, 383-385

It has been shown that cardiac arrest is associated with the development of a considerable metabolic acidosis. This study of 50 consecutive cases of acute myocardial infarction was made to determine whether acute infarction is associated with a metabolic acidosis and whether or not such acidosis is an indication of the severity of the infarct.

\section{Method}

All cases seen and included were those that had suffered an infarct during the four days before admission, having E.C.G. changes of acute infarction, a raised S.G.O.T. of greater than 60 units, or serial E.C.G. changes. On history and clinical examination and E.C.G. findings they were graded according to the prognostic index of Peel et al. (1962). In that index all cases are given scores for age and sex, history, and physical and E.C.G. findings. Any patient with a prognostic index greater than 13-that is, a $25 \%$ chance of dying-and who was under the age of 70, was admitted to the intensive therapy unit when the Sanborn monitor was available. While still in the casualty department, before admission to either a ward or the intensive therapy unit, an arterialized venous sample of blood was removed. Such samples have been shown by Harrison and Galloon (1965) to approximate arterial blood closely. The method used was to immerse the hand in a hot-water bath of approximately $45^{\circ} \mathrm{C}$. for a period of 15 minutes and then remove a sample of blood from a suitable vein at the back of the hand, without compression, into an already heparinized syringe. This sample was then analysed for $\mathrm{Po}_{2}, \mathrm{PCO}_{2}, \mathrm{pH}$, and base deficit by the Astrup microelectrode technique (Astrup et al., 1960). Those patients who were admitted to the intensive therapy unit were monitored by the Sanborn monitor for 72 hours and had continual oxygen by Polymask at 8 litres/minute for a period of 36 hours. In cases of shock the base deficit was corrected by titrated doses of intravenous sodium bicarbonate; at the end of three days the cases were then transferred to a general ward. The other cases were admitted direct into a general ward and had continual oxygen for 36 hours. The patients under 60 in both groups were anticoagulated with heparin and phenindione, and other supportive treatment was given as required.

\section{Results of Investigations}

In the series there were $32(64 \%)$ males and 18 (36\%) females. Ages varied from 41 to 90 . Only those under the age of 70 were accepted for intensive treatment. Age distribution is shown in Table I (Fig. 1) correlated with death-rate and base deficit. Of the 50 patients 12 were selected for intensive therapy unit treatment, of whom seven died.

Of the 50 patients 13 died, three of whom were considered too old to warrant intensive therapy, and in three cases the monitor was unavailable for use. In Table II (Fig. 2) the prognostic index, as shown at the time of admission, is correlated with the expected death percentage, the number of cases which fell into each group, and the death percentage ; the number of

* Barnet General Hospital, Barnet, Herts. Present address : Sydney Hospital, Sydney, N.S.W., Australia. cases who showed a significant base deficit-that is, greater than $-2.5 \mathrm{mEq} / 1$. - and those who ultimately required correction for hypotension are also shown.

TABle I.-Age Distribution, Deaths, and Base-deficit Cases

\begin{tabular}{c|c|c|c|c|c|c|c|c}
\hline \multirow{2}{*}{ Age } & \multicolumn{2}{|c|}{ Cases } & \multicolumn{2}{|c|}{ Deaths } & \multicolumn{2}{|c|}{$\begin{array}{c}\text { Base- } \\
\text { deficit } \\
\text { Cases }\end{array}$} & \multicolumn{2}{|c}{$\begin{array}{c}\text { Base-deficit } \\
\text { Cases } \\
\text { Corrected }\end{array}$} \\
\cline { 2 - 9 } & No. & $\%$ & No. & $\%$ & No. & $\%$ & No. & $\%$ \\
\hline $40-50$ & 4 & 8 & & 0 & 2 & 50 & & 0 \\
$51-60$ & 17 & 34 & 3 & 18 & 9 & 56 & 4 & 22 \\
$61-70$ & 13 & 26 & 4 & 31 & 11 & 90 & 8 & 42 \\
$>70$ & 16 & 32 & 6 & 37 & 11 & 69 & 5 & 45 \\
\hline Total & 50 & & 13 & & 33 & & 17 & \\
\hline
\end{tabular}

TABLE II.-Prognostic Index and Expected Death Correlated with the Number of Cases and Death-rate in This Series. The Number of Acidotic Cases and Those Requiring Correction is Shown

\begin{tabular}{|c|c|c|c|c|c|}
\hline $\begin{array}{l}\text { Prognostic } \\
\text { Index }\end{array}$ & $\underset{\text { Death }}{\text { Expectant }}$ & Cases & Deaths & $\begin{array}{l}\text { Base- } \\
\text { deficit } \\
\text { Cases }\end{array}$ & $\begin{array}{c}\text { Cases } \\
\text { Requiring } \\
\text { Correction }\end{array}$ \\
\hline $\begin{array}{r}1-8 \\
9-12 \\
13-16 \\
17-20 \\
>20\end{array}$ & $\begin{array}{l}2 \% \\
12.5 \% \\
25 \% \\
65 \% \\
85 \%\end{array}$ & $\begin{array}{r}9 \\
21 \\
8 \\
5 \\
7\end{array}$ & $\begin{array}{l}0 \\
6(29 \%) \\
4(50 \%) \\
1(20 \%) \\
2(29 \%)\end{array}$ & $\begin{array}{c}3(33 \%) \\
13(62 \%) \\
6(75 \%) \\
4(80 \%) \\
7(100 \%)\end{array}$ & $\begin{array}{l}0 \\
4(19 \%) \\
3(37.5 \%) \\
3(60 \%) \\
7(100 \%)\end{array}$ \\
\hline
\end{tabular}

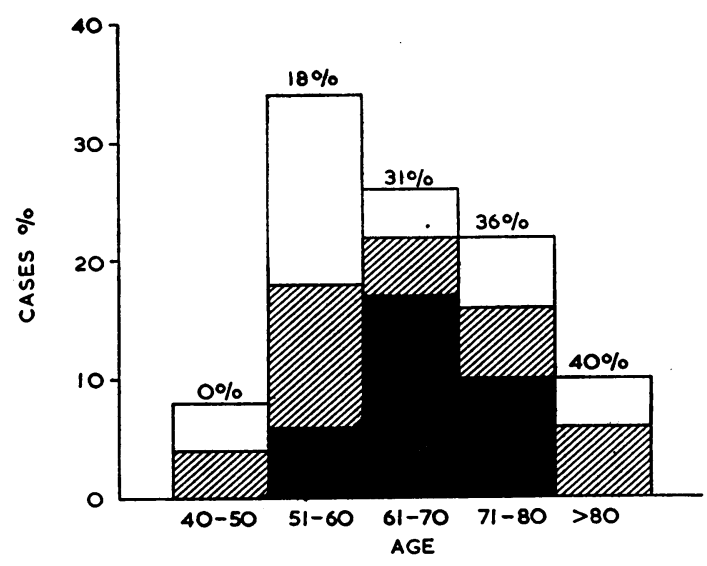

Fig. 1.-Age distribution. Here and in Fig. 2 the shaded areas indicate those cases which had significant base deficits, the black areas those who were corrected. Percentage of deaths is given in each group.

Of the 50 cases thus investigated 33 had a significant base deficit, 15 were within the normal range, and 2 were alkalotic (a base excess greater than $2.5 \mathrm{mEq} / 1$.). Of the 33 acidotic cases 13 had an abnormally low $\mathrm{pH}$ of less than 7.35 , while in the other cases the actual $p \mathrm{H}$ lay within the normal range but each had a significant base deficit. Relationship of the degree of base deficit to death, complications, and 28-day survival is shown in Table III, in which the cases are divided into three groups, depending on the severity of base deficit.

At the conclusion of 28 days the patients were divided into those who were alive and well, those who were alive with complications (most with congestive cardiac failure), and those who had died. Table IV shows the relationship between the base deficit, normal, and corrected cases. 
It will be seen that in this series only 1 of the 17 non-acidotic patients died, whereas the death occurred of 12 of the acidotic patients (this is significant; $\mathrm{P}<0.05$ ), the death-rate being greater in those with an abnormally low $p H$. It should be noted that two of the cases with an abnormally low $p \mathrm{H}$ had sudden onset of cardiac dysfunction-namely, atrial fibrillation and heart-block as well as an acute infarct. This may have been responsible for the low $\mathrm{pH}$, as both did well later and were in the alive-and-well group.

Table $\mathrm{V}$ shows the correlation between the cases whose base deficit was corrected and those in which it was not. The more severe cases, as judged by average prognostic index, were those which required correction, and the death-rate in these two groups is identical. It would appear, therefore, that correction of the acidosis in severe cases improves the prognosis.

By necessity the arterial studies in this series were made at varying times from onset of the infarction-owing to delay in presentation. In order to study the rapidity with which acidosis develops, the cases have been graded into five groups, depending on sample time from onset of infarction.

In each group the average prognostic index has been calculated and the number of base-deficit cases and the death-rate are correlated. The expected death percentage can then be

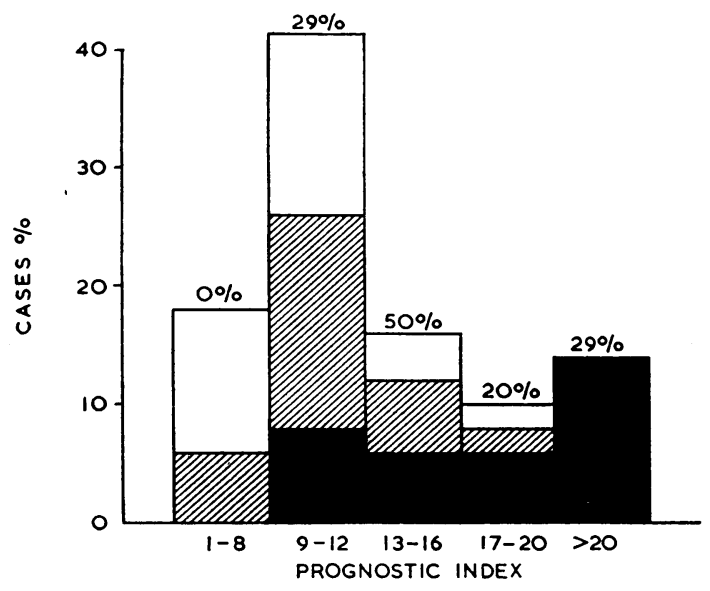

FIG. 2.-Prognostic index.

TABle III.-28-Day Survival Results, the Complications During AdmisTABLE 1I.-28-Day Survival Results, the Complications
sion Against the Degree of Base Deficit

\begin{tabular}{c|c|c|c|c|c|c}
\hline Group & Cases & $\begin{array}{c}\text { Average } \\
\text { Prognostic } \\
\text { Index }\end{array}$ & Deaths & $\begin{array}{c}\text { Heart } \\
\text { Failure }\end{array}$ & $\begin{array}{c}\text { Significant } \\
\text { Hypo- } \\
\text { tension }\end{array}$ & $\begin{array}{c}\text { No } \\
\text { Complica- } \\
\text { tions }\end{array}$ \\
\hline A. Base +4 to -2 & 17 & $9(11 \%)$ & 1 & 6 & 1 & 10 \\
B. \#, -3 & 19 & $12(13 \%)$ & 6 & 3 & 4 & 6 \\
C. above-6 & 14 & $16(24 \%)$ & 6 & 4 & 5 & 1 \\
\hline
\end{tabular}

TABle IV.-28-Day Survival Against the Presence or Absence of Acidosis on Admission

\begin{tabular}{|c|c|c|c|c|}
\hline \multirow[b]{3}{*}{$\begin{array}{l}\text { Alive and well } \\
\text { Alive and complications } \\
\text { Dead }\end{array}$} & \multicolumn{2}{|c|}{$\begin{array}{c}\text { Significant Base Deficit } \\
\text { (33 Cases) }\end{array}$} & \multirow{2}{*}{\multicolumn{2}{|c|}{$\begin{array}{l}\text { No Significant } \\
\text { Base Deficit } \\
\text { (17 Cases) }\end{array}$}} \\
\hline & $\begin{array}{c}\text { Also Low pH } \\
13(26 \%)\end{array}$ & $\begin{array}{l}\text { Normal pH } \\
20(40 \%)\end{array}$ & & \\
\hline & $\begin{array}{l}4(31 \%) \\
3(23 \%) \\
6(46 \%)\end{array}$ & $\begin{array}{r}12(60 \%) \\
2(10 \%) \\
6(30 \%)\end{array}$ & $\begin{array}{r}14 \\
2 \\
1\end{array}$ & $\begin{array}{l}(82 \%) \\
(12 \%) \\
(6 \%)\end{array}$ \\
\hline
\end{tabular}

TABLE V.-28-Day Survival Correlated with the Base Deficit and Normal, Together with Those Corrected. Average Prognostic Index in Each Group is Shown

\begin{tabular}{|c|c|c|c|c|}
\hline 28-day Results & & $\begin{array}{c}\text { No Base } \\
\text { Deficit } \\
(P / I=10)\end{array}$ & $\begin{array}{c}\text { Base Deficit } \\
\text { (Not Corrected) } \\
(\mathbf{P} / \mathbf{I}=11)\end{array}$ & $\begin{array}{l}\text { Base Deficit } \\
\text { (Corrected) } \\
(\mathbf{P} / \mathbf{I}=\mathbf{1 7})\end{array}$ \\
\hline $\begin{array}{l}\text { Alive and well } \\
\text { Dead " complications } \\
\text { Dead }\end{array}$ & $\begin{array}{l}. . \\
\because\end{array}$ & $\begin{array}{l}14(82 \%) \\
2(12 \%) \\
1(6 \%)\end{array}$ & $\begin{array}{l}9(56 \%) \\
1(6 \%) \\
6(38 \%)\end{array}$ & $\begin{array}{l}7(41 \%) \\
4(24 \%) \\
6(35 \%)\end{array}$ \\
\hline Total .. & .. & 17 & 16 & 17 \\
\hline
\end{tabular}

calculated (see Table VI). The average prognostic index in each group is within the same range and therefore the average severity of the infarction is comparable.

TABLE VI.-Time of Infarction Correlated with the Degree of Base Deficit and Death

\begin{tabular}{c|c|c|c|c|c}
\hline $\begin{array}{c}\text { Time from } \\
\text { Onset of Pain } \\
\text { (Hours) }\end{array}$ & Cases & $\begin{array}{c}\text { Average } \\
\text { Prognostic } \\
\text { Index }\end{array}$ & $\begin{array}{c}\text { Number } \\
\text { Deficient }\end{array}$ & Deaths & $\begin{array}{c}\text { Death } \\
\text { Percentage } \\
\text { at Risk }\end{array}$ \\
\hline $0-12$ & 18 & 13 & 12 & 5 & 28 \\
$12-24$ & 9 & 13 & 8 & 2 & 9 \\
$24-48$ & 13 & 12 & 5 & 2 & 5 \\
$48-72$ & 4 & 12 & 2 & 2 & 6 \\
$72-96$ & 6 & 12 & 6 & 1 & $2 \cdot 5$ \\
\hline
\end{tabular}

\section{Correction of Acidosis}

In those patients who were shocked-that is, systolic bloodpressure of less than $90 \mathrm{~mm}$. Hg for more than two hours despite rest and sedation-and who had a significant base deficit, this was corrected by titration with intravenous sodium bicarbonate, the following formula being used:

$$
\mathrm{A}=\mathrm{BW} \times 0.2 \times \mathrm{C}
$$

where $\mathrm{A}=\mathrm{mEq}$ required for correction ; $\mathrm{BW}=$ body-weight in kilograms ; and $\mathrm{C}=$ base deficit in $\mathrm{mEq} / \mathrm{l}$.

All the 12 corrections thus made resulted at least in some rise in blood-pressure, and five patients who had no measurable blood-pressure on admission had a good response (Fig. 3). The five other corrections were for heart-block and arrhythmias. The amount of bicarbonate required for correction varied from 50 to $150 \mathrm{mEq}$ and was generally given as a $2.8 \%$ solution, each $3 \mathrm{ml}$. containing $1 \mathrm{mEq}$ of bicarbonate. In some cases, however, the $8.4 \%$ bicarbonate solution was used in small intermittent doses. This solution is somewhat sclerotic to veins and is best reserved for those cases requiring only slight correction and also for those in which large quantities of intravenous fluids are best avoided.

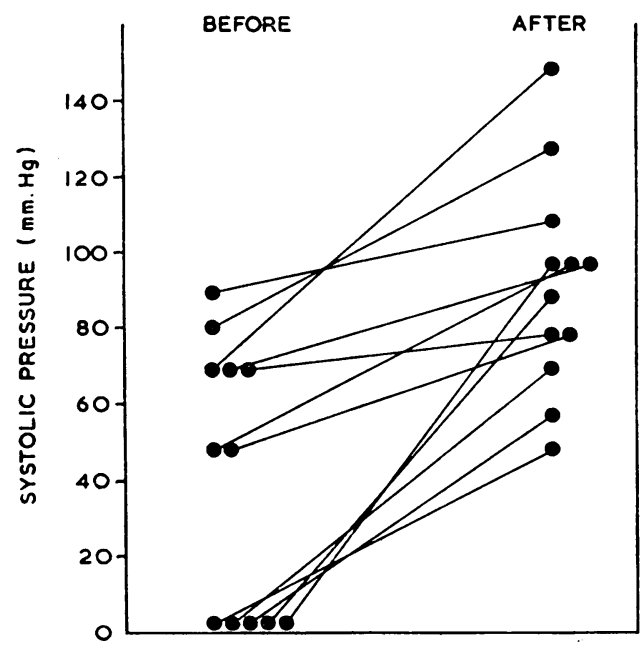

FIG. 3.-Results of 12 corrections made in nine patients, showing the result of infusion of bicarbonate varying from 50 to $165 \mathrm{mEq}$. Systolic pressure before and after correction.

\section{Discussion}

It has been shown by MacKenzie et al. (1964) that cases of acute myocardial infarction suffering from cardiogenic shock have a significant metabolic acidosis and have a poor prognosis. The present study shows that significant base deficit occurs in something like $66 \%$ of acute myocardial infarction and that in the more severe cases correction of this acidosis is accompanied by a rise in pressure and a better peripheral circulation, and may lead to a better prognosis; certainly in our series the 
more severe cases fared better than would have been expected on the prognostic index. In one case the initial diagnosis of myocardial infarction was made on acidosis alone. In another case a severe degree of acidosis preceded cardiac arrest.

It would appear that where poor-risk cases require intensive therapy one method suitable for the selection of such cases is by measurement of the base deficit. In this series there is a significant difference in 28-day survival between acidotic and nonacidotic cases. Certainly base deficit appears to be an indication of the severity of the myocardial infarction. Only one case in 17 with a base deficit greater than minus $5 \mathrm{mEq} / 1$. failed to produce complications.

The site of the infarction does not seem to alter the degree of acidosis. In this study the samples were taken on presentation at the hospital. This time varied considerably from the actual onset of infarction (taken as the onset of severe pain). The samples were then grouped into $0-12,12-24,24-48$, and 48-72 hours post-infarction. A significant base deficit measured within the first 12 hours carried a $28 \%$ mortality, within $12-24$ hours a $9 \%$ mortality, and within $24-48$ hours a $5 \%$ mortality.

It must be remembered that there are other causes of metabolic acidosis, such as uraemia and diabetes, and these must be excluded before the whole acidosis is thought to be due to the myocardial infarct. It would also appear reasonable from this study that the correction of the acidosis may improve the prognosis, and a trial is at present in progress to establish whether correction of the acidosis improves prognosis and reduces complications.

\section{Summary}

Fifty cases of acute myocardial infarction have been investigated with respect to the development of metabolic acidosis.

In this series $66 \%$ of such cases developed a significant acidosis.

In a proportion of shocked cases correction with intravenous sodium bicarbonate resulted in a rise in systolic blood-pressure.

Of the 50 patients $13(26 \%)$ died within 28 days. Twelve of the fatal cases in this series showed a significant base deficit, only one being in the non-acidotic group. The non-acidotic patients had a significantly better prognosis.

Measurement of metabolic acidosis may be a useful guide to the degree and severity of acute myocardial infarction. A significant base deficit occurring within 12 hours of infarction carried a $28 \%$ mortality in this series.

I would like to thank Dr. G. R. Royston for permission to study the cases under his care, Dr. J. Collis for statistical work, and Miss V. Spiller for secretarial work.

\section{REFERENCES}

Astrup, P., Jørgensen, K., Andersen, O. S., and Engel, K. (1960). Lancet, 1, 1035.

Harrison, E. M., and Galloon, S. (1965). Brit. F. Anaesth., 37, 13. MacKenzie, G. J., Taylor, S. H., Flenley, D. C., McDonald, A. H., Staunton, H. P., and Donald, K. W. (1964). Lancet, 2, 825.

Peel, A. A. F., Semple, T., Wang, I., Lancaster, W. M., and Dall, J. L. G. (1962). Brit. Heart f., 24, 745 .

\title{
In-vivo Cell Kinetics of a Normal Human Tissue*
}

\author{
GEORGE WIERNIK, $†$ M.D., D.M.R.T.
}

Brit. med. F., 1966, 2, 385-387

Very little is known at present of the cell kinetics in an organized human tissue owing to the ethical difficulties which prevent the application of techniques that have been used in experimental animals. Most of these techniques rely on a substance carrying a radioactive label which is incorporated into the nucleus of the cell at the time of D.N.A. synthesis. Limited studies of the cell kinetics of the human small-intestinal mucosa by the use of tritiated thymidine have been reported (Lipkin, Sherlock, and Bell, 1963 ; MacDonald, Trier, and Everett, 1964 ; Shorter, Moertel, Titus, and Reitemeier, 1964).

The present study has revealed the basic pattern of response to damage of an organized tissue and the repair thereof as it occurs in the human jejunal mucosa. The damage was caused by a dose of $x$-irradiation which affected mainly the crypt epithelial cells ; the dose was insufficient to produce observable effects in the adult epithelial cells on the villi (Quastler, 1959), so that any changes could be considered to be secondary to damage of the crypt epithelial cells. Further, it was thought that irradiation caused non-specific damage to the crypt cells, which form the proliferative compartment of the epithelial cells lining the intestinal mucosa. It has been shown that this dose of irradiation (Wiernik, Shorter, and Creamer, 1962) produced

* This investigation formed part of an M.D. Thesis.

t Assistant Radiotherapist, Department of Radiotherapy, St. Thomas's Hospital, London. Present address: Department of Radiotherapy, Churchill Hospital, Headington, Oxford. similar effects to those of antimitotic drugs (Dustin, 1950 ; Baserga and Morsiani, 1958) in the small intestine of the rat.

\section{Method}

Peroral Biopsy Technique.-The patient in whom this study was conducted was selected from among those whose treatment entailed irradiation of the abdomen when the jejunum was within the area to be treated. Jejunal biopsy, when the pylorus and duodenum have to be negotiated, can be an unpleasant and prolonged procedure which cannot be repeated at short intervals. When direct access to the jejunum becomes possible through prior surgical procedures jejunal biopsy, though no more pleasant, is a rapid procedure, and because of this the patient tolerated it on several occasions. The patient was referred for post-operative irradiation after a Polya-type partial gastrectomy for carcinoma of the stomach. The technique was fully explained to the subject, who was given the option of receiving conventional treatment or of participating in this experimental technique. The patient had fasted for at least two hours before biopsy. Adequate local anaesthesia of the back of the throat was obtained with gargles of $2 \%$ lignocaine hydrochloride, which permitted swallowing of the Crosby peroral jejunal biopsy capsule (Crosby and Kugler, 1957 ; Crosby, 1963). With 